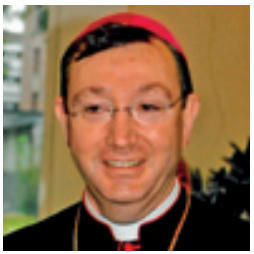

\title{
Eutanasi og spøkelsene fra fortiden
}

\begin{abstract}
Hedmark Høyre har med sitt utspill om legalisering av aktiv dødshjelp satt fart i debatten rundt dette kontroversielle tema. Frihet for enkeltmennesket er argumentet som brukes for å rettferdiggjøre forslaget. Det liberale menneske kan altså ikke nekte et selvstendig individ å avslutte sitt eget liv.
\end{abstract}

Ordet «eutanasi», av gresk opprinnelse, var ensbetydende med en god og ærerik død. Som leserne selvsagt vet skilles det i den moderne legevitenskap mellom såkalt passiv og aktiv dødshjelp. La oss her definere «aktiv dødshjelp» som en leges aktive inntreden, med pasientens samtykke, med medikamenter eller teknikker som fremskynder pasientens død. Denne formen for dødshjelp kalles ofte «barmhjertighetsdrap». Moralsk sett legitimeres dette altså ut ifra barmhjertighetsprinsippet. Det er et farlig ord å ta i sin munn. Forsvarerne av aktiv dødshjelp bør se på erfaringer fra Nederland og ikke minst europeisk historie fra 1900-tallet før de definitivt taler dets sak. For hvilken ideologi stammer eutanasien fra, og hvilke konsekvenser kan vi ane for det moderne mennesket dersom vi får en lovgivning som legaliserer den?

\section{«Det uverdige liv»}

Alfred Hoche \& Karl Bindings bok fra 1920, Die Freigabe der Vernichtung lebensunwerten Lebens (Retten til å tilintetgjøre det uverdige liv), er blitt stående som et skrekkens eksempel på eutanasiens ytterste konsekvens. Tanken var at psykisk og fysisk syke mennesker representerte en moralsk og økonomisk belastning for sam- funnet og derfor med rette kunne avlives ut fra en utilitaristisk moral - den syke delen av samfunnets kropp måtte fjernes for helhetens ve og vel. Hoche fikk dessverre realisert sine ideer allerede i sin egen levetid, gjennom nazistenes T4-plan for eutanasi i 1930-årenes Tyskland.

Uhyrlighetene ble også forsøkt innført i Norge ved opprettelsen av Quisling-regimets nye helseavdeling i 1941, hvor man i Hoche \& Bindings ånd søkte «avlivning av uhelbredelige sinnssyke fra en håpløs og meningsløs tilværelse»».

\section{Samfunnet som normgiver}

Det er klart at Hedmark Høyre eller andre advokater for aktiv dødshjelp ikke ønsker å bli assosiert med disse historiens skampletter. De er imidlertid verdt å ha i bakhodet, da deler av historien som kjent har en tendens til å gjenta seg selv. Hva kan vi så lære av våre forfedres erfaringer og erkjennelser, og hvilke ideologier er det i dag som åpner for at visse typer liv ikke er verdt å leve?

I moderne liberalisme kan vi ane konturene av et menneskesyn hvor individet alene er sin egen normgiver. Men individet lever ikke i et vakuum, adskilt fra samfunnet for øvrig. De rådende krav fra samfunnet og mediene om effektivitet, nyttighet og kreativitet er massive. At dette påvirker individet, skulle det være unødvendig å verifisere. Hva har så dette med aktiv dødshjelp å gjøre?

\section{Sorteringssamfunnet}

Jeg frykter at et ja til aktiv dødshjelp kan føre til et indirekte press på sårbare mennesker til å avslutte sitt eget liv. Problemet er nettopp signaleffekten samfunnet gir til sine syke og svake, de som befinner seg langt borte fra offentlighetens krav til nytteverdi og produktivitet. Det sies indirekte «det er lov å gi opp» og «ditt liv er ikke verdt å kjempe for» - en slags liberal nihilisme som i sin ytterste konsekvens gir oss assosiasjoner til sorteringssamfunnet.

Det er stor forskjell på personlig frihet og råderett over eget liv og retten til å ta sitt eget liv. Ifølge norsk lov er det straffbart for alle borgere å bidra til å ta liv. Jeg vil med dette ta sterkt til orde for en fortsettelse av denne praksis, både i juridisk og moralsk forstand. La oss lære av historien der vi kan. Å overtrede én grense vil kunne føre til krav om å flytte på flere. Grensene er hele tiden flytende, og vi kan ikke vite hvor det ender. Det ser vi ikke minst i Nederland. Da aktiv dødshjelp ble legalisert i 2002, var kravet at pasienten måtte ha en uhelbredelig sykdom og mindre enn seks måneder igjen å leve. Kriteriene er nå dramatisk utvidet til å gjelde både kronikere, psykisk syke og «livstrette» mennesker. Er det i denne retning vi ønsker å gå?

\section{Ville leve likevel}

En undersøkelse i Pallative Medicine, tidligere omtalt i dette tidsskrift, viser at synet på aktiv dødshjelp hos pasienter med forventet kort levetid var ambivalent og varierte sterkt fra dag til dag. Individet kan altså ha store problemer med å tenke klart og rasjonelt i ekstreme livssituasjoner. Er det den fysiske smerten eller den åndelige og psykiske nød som er avgjørende for et eventuelt valg? Seksjonsoverlege Jens Christian Vik ved Sykehuset Innlandet Gjøvik fortalte på NRKs Østnytt i mars 2008 at han tidligere var for aktiv dødshjelp. Etter å ha jobbet med alvorlig syke i flere år innså han sin feilslutning. «I løpet av disse fire årene er det bare en som har spurt om hjelp til å dø. Jeg svarte selvfølgelig nei. Jeg prøvde å hjelpe henne så mye som mulig med hennes plager. Etter et par uker ville hun leve likevel.»

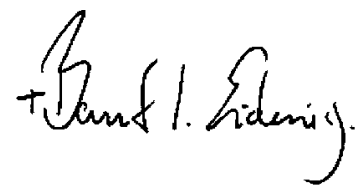

Tema: selvskading

Sikkerhetspsykiatrien

Jus og medisin
Akuttmedisin i Utkant-Norge

Kalprotektin

Graves' sykdom 